\title{
Drosera ultramafica (Droseraceae), a new sundew species of the ultramafic flora of the Malesian highlands
}

\author{
A. Fleischmann ${ }^{1}$, A.S. Robinson ${ }^{2}$, S. McPherson ${ }^{3}$, V. Heinrich ${ }^{4}$, E. Gironella ${ }^{5}$, \\ D.A. Madulid ${ }^{6}$
}

Key words

carnivorous plants

Drosera

Droseraceae

Kinabalu

Malesia

new species

Palawan

Philippines

ultramafics
Abstract Drosera ultramafica, a new montane sundew species endemic to ultramafic soils of the Malesian highlands, is described and illustrated.

Published on 9 February 2011

\section{INTRODUCTION}

Ultramafic soils are highly infertile substrates with unusual rock chemistry (Proctor \& Woodell 1975, Proctor 2003). Such soils are commonly referred to as 'serpentine' by plant ecologists, however this term defines a group of minerals, whereas 'ultramafic' or 'ultrabasic' is preferred for rocks, their derived soils and endemic flora (Gibson et al. 1992). These soils are generally poor in plant macronutrients such as nitrogen, phosphorous, potassium and calcium, but also toxic to most plant life due to their high concentrations of nickel, cobalt, chromium and magnesium (Proctor \& Woodell 1975, Gibson et al. 1992). Even so, many plants are adapted to ultramafic soil conditions, resulting in a specialized ultramafic flora that often contrasts sharply with the surrounding vegetation in terms of species composition and general appearance, often being rich in endemic taxa (Proctor \& Woodell 1975, Brooks 1987).

Ultramafic outcrops are widespread in Malesia (see Map 1), including large areas of Sulawesi, New Guinea and the Philippines (Brooks 1987, Proctor 2003). The low soil nutrient content of ultramafics leads to a rather open vegetation (Nagy \& Proctor 1997), providing conditions ideally suited to carnivorous plants, which are adapted to survive on poor soils through the capture of invertebrate prey for additional nutrition. Indeed, a high $\alpha$-diversity of Nepenthes L. (Nepenthaceae) is confined to ultramafic soils in Malesia (Robinson et al. 2009).

\footnotetext{
University of Munich, Dept. 1, Systematic Botany and Mycology, Menzinger Strasse 67, 80638 Munich, Germany;

corresponding author e-mail: fleischmann@Irz.uni-muenchen.de.

2 Institute of Education, University of London, 20 Bedford Way, London, WC1H 0AL, United Kingdom.

${ }^{3}$ Redfern Natural History Productions, 61 Lake Drive, Hamworthy, Poole, Dorset, BH15 4LR, United Kingdom.

${ }^{4}$ Purok 2, Kalasungay, Malaybalay City, Bukidnon Province, Philippines 8700.

${ }^{5}$ Biodiversity Center for Research and Conservation, Palawan State University, Puerto Princesa City, Palawan, Philippines 5300.

6 National Museum, Botany Division, P.O. Box 2659, Manila, Philippines.
}

A single, widespread species of Drosera L., Drosera spatulata Labill. has been reported to occur occasionally on ultramafics in Malesia (Van Steenis 1953, Beaman et al. 2001). However, a closer examination of the $D$. spatulata aggregate by the first author of this study revealed that the ultramafic plants do not represent $D$. spatulata s.I., but a distinct species that has not been described thus far.

In his treatment of Droseraceae for Flora Malesiana, Van Steenis notes under $D$. spatulata: "The Sumatran and Philippine specimens [referring to $D$. spatulata s.str. sensu Labill., collected on the Philippine islands of Luzon and Mindoro] differ slightly from those of Mt Kinabalu [D. ultramafica] by obovate, not acute, petals with slight crenulations towards the apex, by broader bracts, and by a scarcely capitate-glandular inflorescence. The style-arms are sometimes halfway forked for a second time." (Van Steenis 1953). Moreover, this new, stem-forming Drosera had already been reported and pictured from Marai Parai several times under the name $D$. spatulata (e.g. Diels 1906, Van Steenis 1953, Beaman et al. 2001, Anfraix 2005), as well as from Leuser National Park of northern Sumatra (De Wilde \& Duyfjes 2001). A recent expedition to the Philippines (see Robinson et al. 2009, McPherson 2009) has revealed the presence of this new taxon from ultramafic habitats on two different mountains located on the island of Palawan. It is described here from herbarium specimens and observations made during that expedition.

\section{MATERIAL AND METHODS}

Herbarium specimens were studied for morphological measurements and taxonomical comparison (A.F.) and notes on habitat and ecology were recorded from the field in Palawan (A.S.R.). 


\section{DESCRIPTION OF SPECIES}

Drosera ultramafica A.Fleischm., A.S.Rob. \& S.McPherson, sp. nov. - Fig. 1, 3, Map 1

A Drosera spatulata Labill. caule brevi, foliis suberectis, lamina anguste oblanceolata vel oblonga, et stigmatibus spathulatis vel bilobatis recedit. - Typus: McPherson 002 (holo PPC; iso L), Philippines, Palawan, Mt Victoria, high montane forest on ultramafic soils, 1680 m alt., 24 June 2007.

Etymology. The epithet denotes the fact that this species is confined to ultramafic soil.

Stem-forming rosetted perennial herb. Stem with short internodes, forming short stems up to $5 \mathrm{~cm}$ with age. Leaves narrowly oblanceolate to oblong, semi-erect, green to deep red in colour, (10-)20-40 $\mathrm{mm}$ long, up to $5 \mathrm{~mm}$ wide near the tip; stipules papery, 3-laciniate, white to reddish (drying brown), 5-7 mm long, up to $2 \mathrm{~mm}$ wide at the base. Scapes 1-4; inflorescence a 1-sided raceme, rarely forked; flowers (2-)4-15; peduncle terete, slightly ascending at the base, $1-1.5 \mathrm{~mm}$ diam, up to $20 \mathrm{~cm}$ long; peduncle base with simple, appressed nonglandular hairs c. $0.5 \mathrm{~mm}$ long, median part of scape subglabrous; uppermost part of scape, bracts and pedicels covered with short stalked glandular trichomes or subglabrous. Pedicels terete, short, 1-4 mm long; bracts subulate to narrowly triangular with apex acute, 2-2.5 mm long, c. $0.2 \mathrm{~mm}$ wide; calyx subcampanulate, with subsessile glandular trichomes; sepals 5 , narrowly elliptical to narrowly triangular, with apex acute, apex sometimes reflexed in fruit, 3-6 mm long, $1-1.5 \mathrm{~mm}$ wide, with subsessile glands, especially near the apex; petals 5 , obovate to cuneate, with crenulate margin, $8-9 \mathrm{~mm}$ long, 3.5-4 $\mathrm{mm}$ wide, white or pink. Stamens 5 , filaments $3-5 \mathrm{~mm}$ long, c. 0.1 $\mathrm{mm}$ wide, white; thecae $1 \mathrm{~mm}$ long, anthers and pollen yellow; styles 3 , forked at $1 / 3-1 / 4$ of their length, $3-4 \mathrm{~mm}$ long, c. 0.4 $\mathrm{mm}$ wide near the base, stylar arms c. $0.1 \mathrm{~mm}$ wide, stigmatic tips lanceolate to spathulate or bifid, $0.2-0.3 \mathrm{~mm}$ wide; ovary subglobose; capsule subglobose, c. $3 \mathrm{~mm}$ long, c. $2 \mathrm{~mm}$ diam, opening by longitudinal slits; seed ellipsoid, apiculate, black, c. $0.4 \mathrm{~mm}$ long, c. $0.2 \mathrm{~mm}$ wide, testa reticulate.

Distribution - Malesia: Philippines, Palawan, Mt Mantalingahan and Mt Victoria; Malaysia, Borneo, Sabah, Mt Kinabalu; Indonesia: Sumatra, Northern Sumatra, Aceh, Gunung Bandahara and Pucuk Angasan; Sulawesi, Central Sulawesi, Buyu
Katapasa. Drosera ultramafica is recorded from a number of high elevation (1500-3000 m) sites in Malesia thus far, and it is likely to be more widespread on suitable mountain ranges in the Malesian Archipelago. Drosera ultramafica has been observed and pictured growing at the summit of Buyu Katapasa in northern Central Sulawesi at 2700 m (U. Zimmermann, pers. obs.), but no herbarium specimens are yet available for Sulawesi (Map 1).

Habitat \& Ecology - High montane forest, on ultramafic soils, $1500-3000 \mathrm{~m}$.

Sparsely scattered populations in Palawan at 1600-1700 m altitude in seepages on sharply-draining rocky soil. On Mt Mantalingahan, found growing in granular ultramafic soil on open seepages in full sun and among grasses. On Mt Victoria, found primarily among grasses and ultramafic protrusions in well-drained soils thoroughly wetted by regular downpours. Flowers and fruits observed July-August. Plants generally shaded, but exposed to intense midday sunlight and cooled by heavy cloud thereafter. June temperatures to $30^{\circ} \mathrm{C}$ during the day, $16{ }^{\circ} \mathrm{C}$ at night (pers. obs.). On Mt Victoria, associated species consist predominantly of a Pleomele sp. (Asparagaceae), as well as Leptospermum (Myrtaceae), Vaccinium (Ericaceae) and Medinilla spp. (Melastomataceae), various grasses and Nepenthes attenboroughii A.S.Rob., S.McPherson \& V.B.Heinrich (Robinson et al. 2009).

On Mt Kinabalu in lower montane forest, growing in damp to boggy openings on ultramafic substrate from 1500-1700 m elevation (Van Steenis 1953, Beaman et al. 2001).

In Northern Sumatra, Aceh, on Gunung (Mt) Bandahara and Pucuk Angasan (and probably other mountain summits of the Gunung Leuser National Park), D. ultramafica grows in wet 'mountain blang vegetation' (open montane areas with heathlike vegetation, see De Wilde \& Duyfjes 2001) at altitudes of 2300-3000 m. The soil of these mountain 'blang' areas is very infertile and it has been shown to be rich in heavy minerals (Van Beek 1982), over a base of basaltic rock (Hutchison 1975). The Sumatran plants of $D$. ultramafica are generally smaller in overall size, compared to the plants of Kinabalu or Palawan, with rosettes reaching $2-3 \mathrm{~cm}$ diam, and scapes rarely exceeding 4 $\mathrm{cm}$ in height. Dwarfed plants from the summit areas of Gunung Pucuk Angasan growing in exposed areas in heavy grey clay at

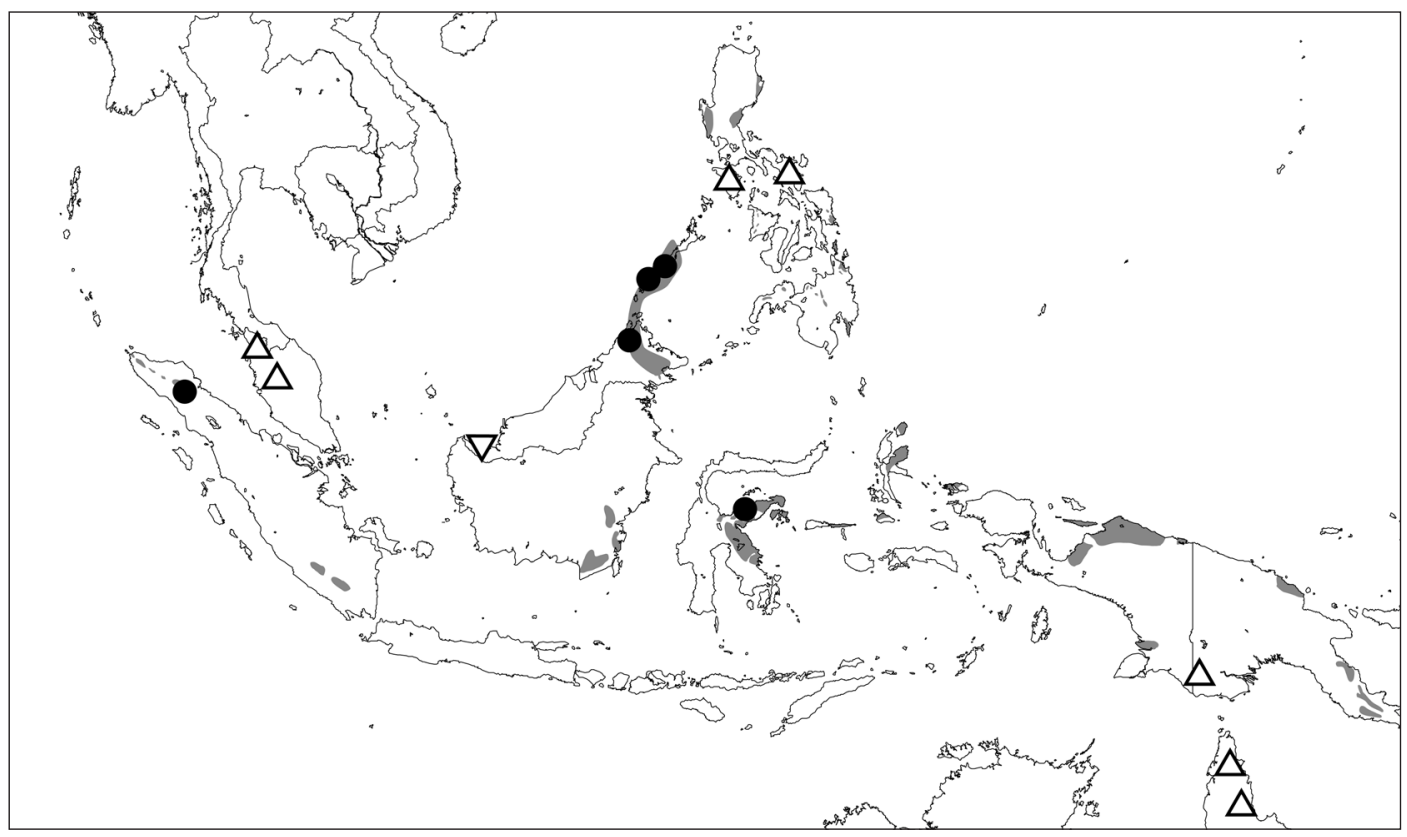

Map 1 Distribution of Drosera ultramafica $(\bullet), D$. spatulata var. spatulata $(\triangle)$ and $D$. spatulata var. bakoensis $(\nabla)$ in Malesia. Grey shading indicates areas of ultramafic rock (modified from Brooks 1987 and Hutchison 1975). Drosera spatulata is also indicated for adjacent northern Australia, Cape York, where it is locally common, see Lowrie 1998. 


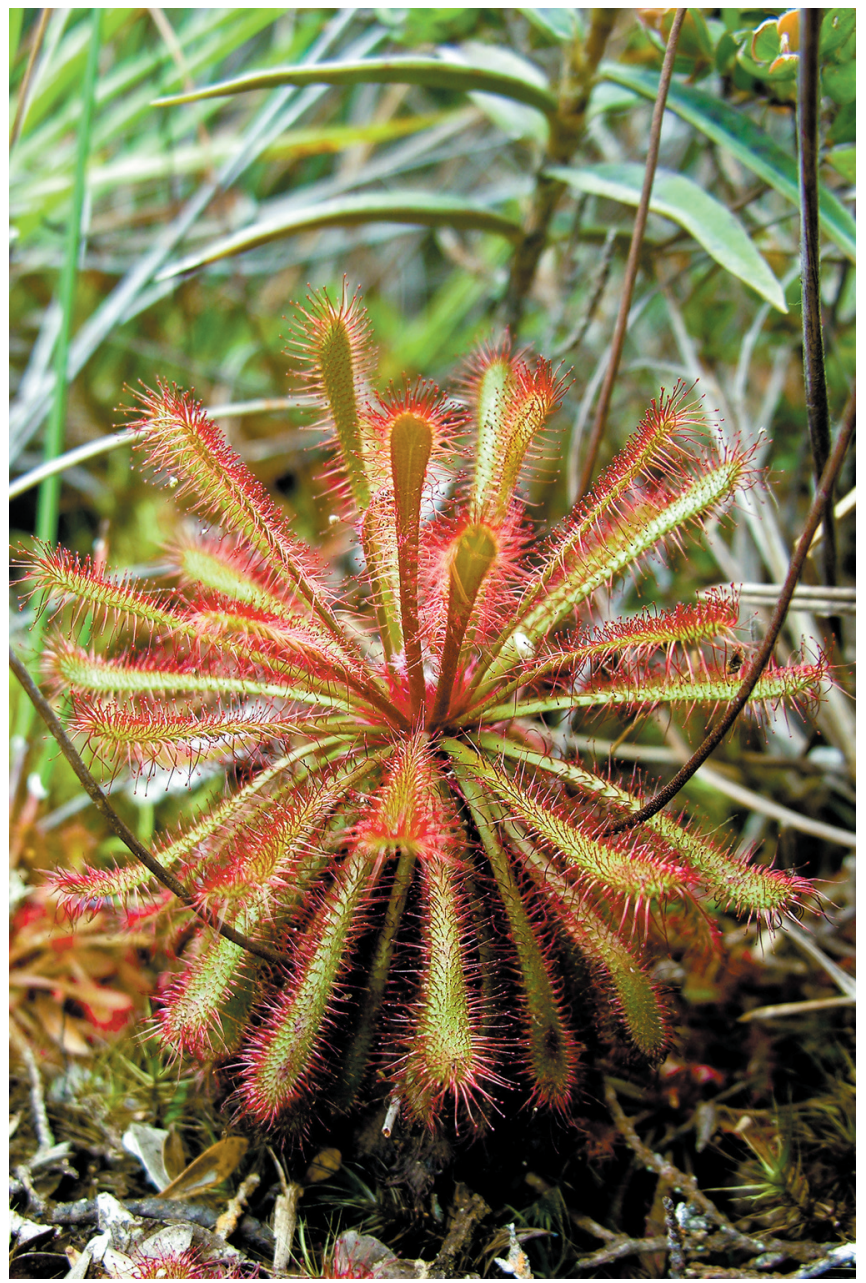

Fig. 1 Drosera ultramafica on Mt Mantalingahan, Palawan. Photo S. McPherson.

$3000 \mathrm{~m}$ (W.J.J.O. de Wilde \& B.E.E. de Wilde-Duyfjes 16360) have scapes only $1 \mathrm{~cm}$ in length and rosettes $\pm 1.5 \mathrm{~cm}$ diam. Plants of $D$. ultramafica from Aceh are often associated with the locally endemic carnivorous plant Utricularia steenisii P.Taylor (e.g. intermixed in collection W.J.J.O. de Wilde \& B.E.E. de Wilde-Duyfjes 15283).

Conservation status - Not threatened.

Specimens examined.

Drosera ultramafica: PHILIPPINES, Palawan, Mt Victoria, $1680 \mathrm{~m}$, 24.06.2007, McPherson 002 (holo PPC; iso L); Palawan, Mt Mantalingahan, along slopes of Ulut Tigaplan ridge, c. $1800 \mathrm{~m}$, on moss-covered rock at the depauperate heath formation, 10.04.1977, L.L.Co 1780 (L, PNH). - MALAYSIA, Borneo, Sabah, Mt Kinabalu, Marai Parai, 5000 ft. [1500 m], 21.03.1933, J. \& M.S. Clemens 32233 (K, L, M); 1700 m, Haviland 1268 (K); Marai-Parai ridge, growing in exposed damp areas, flowers pink, 15.01.1983, collector unknown SNP 1025 (K, L, PNH, SAR); 1500 m, Collenette A 95 (BM, photograph); Marai Parai Spur, M.S. Clemens 10908 (K), 1500-1700 m; Gibbs 4040 (BM, photograph); Topping 1886 (K!); Mt Kinabalu, 1500 m, Low s.n. (K). - INDONESIA, Sumatra, North Sumatra, Gajo Lands, Gunung Leuser Nature Reserve, Atjeh [Aceh], 2300-2600 m, blang vegetation, wet, open place with very short vegetation, plant reddish, flowers pink, 28.02.1975 W.J.J.O. de Wilde \& B.E.E. de Wilde-Duyfjes 15141, 15158, 15283, 16078 (all L); 2725 m, camp 2-3, P. Angasan 15969 (L); 3000 m, 16360 (L); mountain heath ('blang'), field of Scirpus, Cladium and sedges, heavy gray clay, locally common, flowers pink, c. $2000 \mathrm{~m}, 21.02 .1973$, C.G.G.J. van Steenis 9085 (L); Putjuk Angasan, spur to Mt Losir [Gunung Losir], open mountain heath, c. $2300 \mathrm{~m}, 28.01 .1973$, C.G.G.J. van Steenis 8332 (L); Gunung Bandahara, camp 6, damp 'blang', exposed, wet places, plants reddish, flowers pink, 2600-2700 m, 24.06.1972, W.J.J.O. de Wilde \& B.E.E. de Wilde-Duyfjes 13307 (L).

Drosera spatulata: PHILIPPINES, Luzon, Cuming 857 (L, M); Luzon, Albay Province, Mayon Volcano, road cut, open slope, $1015 \mathrm{~m}$, flowers white, 04.06.1953, D.R. Mendoza 18321 (L); Mindoro, Mt Halcon, in open heaths,

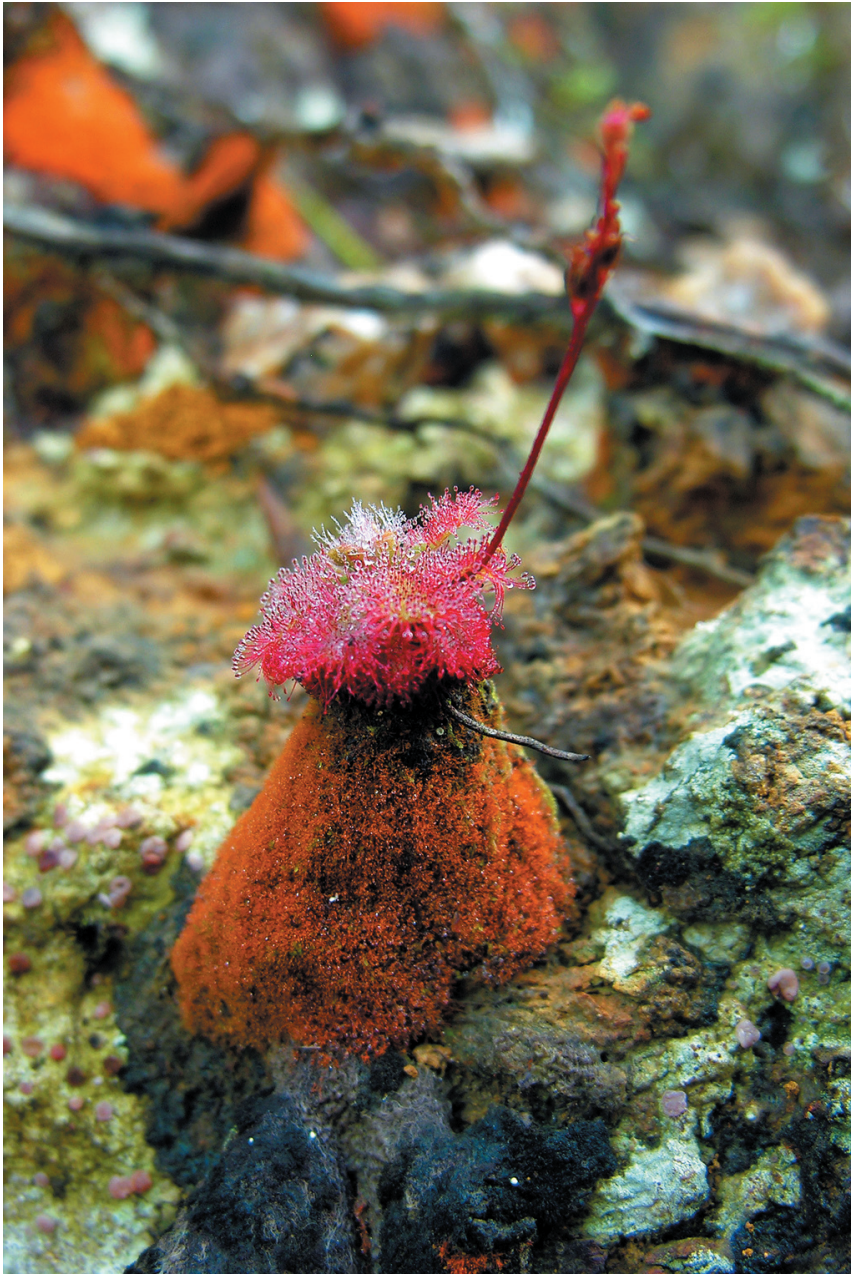

Fig. 2 Drosera spatulata on Mt Halcon, Mindoro. Photo A.S. Robinson.

2400 m, locally abundant, Merrill 5784 (?, not seen). - MALAYSIA, var. spatulata: Malay Peninsular, Kedah Peak, Holttum 14880 (SING); var. bakoensis: NW Borneo, Sarawak, Bako Plateau, J.W. Purseglove P4926 (L, SAR); P.S. Ashton S17920 (L); Telok Pandan path, c. 90 m [300'], 4.5.1959, J. Carrick \& I.C. Enoch JC/473 (holotype SAR); Pedang, 90 m [300'], 22.4.1959, J. Carrick \& I.C. Enoch JC/49 (SAR); Teluk Assam, heath woodland, 120 m [400'], 17.5.1955, J.W. Purseglove P4927 (spirit material) (SAR); Lintang path, sides of paths in open places free of litter, especially damp places, acid soil, 4.6.1963, P.S. Ashton S17920 (L, SAR). - PAPUA NeW GuINEA, Western Province, Wassi Kussa River, Tarara, on wet ground in savannah forest, rare herb, flowers white, Jan. 1937, L.J. Brass 8752a (A n.v., LAE n.v.); New Britain, Hoskins Sub-District, NNE slope Mt Ulawon [Mt Ulawun], on top of north-facing cliff, c. 14 feet tall, habit damp, plants in sun bright red and very conspicuous, those in shade pale green apart from red gland, corolla pink, 4300 feet [c. 1300 m], 20.02.1971, P.F.Stevens LAE51255 (L).

Notes - Plants of $D$. ultramafica from Palawan and Central Sulawesi have white petals, whereas plants from Northern Sumatra are pink-flowered. Specimens from Mt Kinabalu, Borneo, are reported to have both pink and white flowers.

Interestingly, seedlings of $D$. ultramafica bear conspicuous short-stalked glands on their cotyledons. Glandular cotyledons are occasionally found in Drosera species of section Drosera (Conran et al. 1997).

In the Malesian area, $D$. ultramafica is unlikely to be confused with any other Drosera species except $D$. spatulata (for differences see Table 1). In the field, sterile plants of $D$. ultramafica can be distinguished from $D$. spatulata on sight by their stemforming habit and by the erect to semi-erect narrowly oblong to oblanceolate leaves, which give the overall plant a subglobose appearance (Fig. 1). In contrast, the spathulate to cuneate leaves of $D$. spatulata are appressed to the ground, forming a 


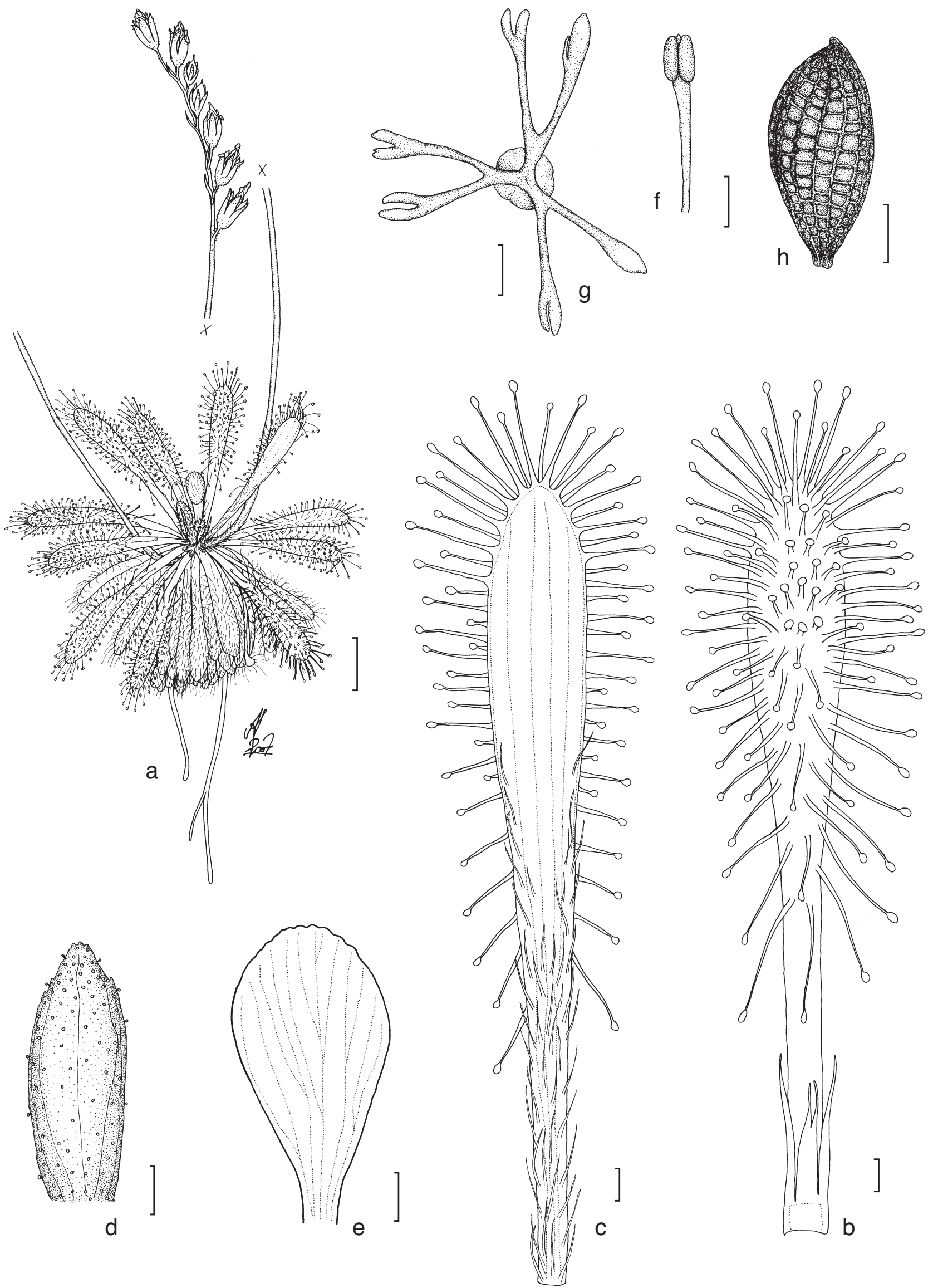

Fig. 3 Drosera ultramafica A.Fleischm., A.S.Rob. \& S.McPherson. a. Habit of plant in fruit; b. leaf with stipule, adaxial view; c. leaf, abaxial view, stipule removed; d. sepal; e. petal; f. anther; g. ovary and styles; $h$. seed (all: McPherson 002). - Scale bars: $a=1 \mathrm{~cm} ; \mathrm{b}-\mathrm{g}=1 \mathrm{~mm} ; \mathrm{h}=0.1 \mathrm{~mm}$. Drawn by A. Fleischmann. 
Table 1 Comparison of the related species Drosera ultramafica, D. neocaledonica, D. oblanceolata and D. spatulata s.I. Both Drosera spatulata Labill. var. spatulata and D. spatulata var. bakoensis A.Fleischm. \& Chi C.Lee, a microendemic from the Bako plateau of south-western Sarawak, Borneo, occur in the Malesian floristic area.

\begin{tabular}{|c|c|c|c|c|}
\hline & Drosera ultramafica & D. neocaledonica & D. oblanceolata & D. spatulata \\
\hline habit & $\begin{array}{l}\text { stem-forming rosette, } \\
\text { leaves semi-erect }\end{array}$ & $\begin{array}{l}\text { stem-forming rosette, } \\
\text { leaves semi-erect }\end{array}$ & $\begin{array}{l}\text { basal rosette, } \\
\text { leaves semi-erect }\end{array}$ & $\begin{array}{l}\text { basal rosette, leaves appressed } \\
\text { plain to the ground }\end{array}$ \\
\hline lamina & $\begin{array}{l}\text { narrowly oblanceolate } \\
\text { to oblong }\end{array}$ & $\begin{array}{l}\text { narrowly spathulate to oblong, } \\
\text { conspicuous white hairs }\end{array}$ & oblanceolate to linear & spathulate to narrowly cuneate \\
\hline scape & $\begin{array}{l}\text { hairy at the base, subglabrous } \\
\text { to glandular in upper part }\end{array}$ & $\begin{array}{l}\text { hairy at the base, densely covered } \\
\text { with red glandular trichomes }\end{array}$ & subglabrous & $\begin{array}{l}\text { covered with short-stalked glandu- } \\
\text { lar trichomes, sometimes hairy at } \\
\text { the base }\end{array}$ \\
\hline pedicels & $1-4 \mathrm{~mm}$, subglabrous to glandular & $2-5 \mathrm{~mm}$, glandular & $3-5 \mathrm{~mm}$, subglabrous & $0.2-3 \mathrm{~mm}$, glandular \\
\hline sepals & $\begin{array}{l}3-6 \mathrm{~mm} \text { long, narrowly elliptic } \\
\text { to triangular, subglabrous to } \\
\text { glandular }\end{array}$ & $\begin{array}{l}3.5-4 \mathrm{~mm} \text { long, elliptic or narrowly } \\
\text { ovate, glandular }\end{array}$ & $\begin{array}{l}\text { c. } 4 \mathrm{~mm} \text { long, narrowly obovate } \\
\text { to oblong, glabrous }\end{array}$ & $\begin{array}{l}3-5 \mathrm{~mm} \text { long, lanceolate or oblong, } \\
\text { glandular }\end{array}$ \\
\hline petals & $\begin{array}{l}8-9 \text { by } 3.5-4 \mathrm{~mm} \text {, obovate to } \\
\text { cuneate }\end{array}$ & $\begin{array}{l}10 \text { by } 4-5 \mathrm{~mm} \text {, cuneate to } \\
\text { obovate }\end{array}$ & obovate to cuneate & $3.5-6 \mathrm{~mm}$, obovate to oblong \\
\hline styles & $\begin{array}{l}\text { divided at the base, stigmatic tips } \\
\text { lanceolate to spathulate or bifid }\end{array}$ & $\begin{array}{l}\text { divided at the base, multibranched } \\
\text { stigmatic tips }\end{array}$ & $\begin{array}{l}\text { divided at the base, bifid or } \\
\text { ramose }\end{array}$ & $\begin{array}{l}\text { divided at the base, stigmatic tips } \\
\text { entire or rarely bifid, terete, } \\
\text { narrowed to the tip }\end{array}$ \\
\hline seed & $\begin{array}{l}\text { ellipsoid, apiculate, black, } \\
\text { reticulate }\end{array}$ & $\begin{array}{l}\text { ellipsoid, apiculate, minutely } \\
\text { foveolate }\end{array}$ & ellipsoid, black & ellipsoid, apiculate, granulate \\
\hline
\end{tabular}

flat rosette. Occasionally, old specimens of $D$. spatulata may form tall columns consisting of dried leaves (e.g. observed on Mindoro, Fig. 2), but even in these individuals, the leaves are never held erect to semi-erect as in D. ultramafica. The colour of the stipules of living plants is another useful character to tell both species apart: the membranous stipules of $D$. ultramafica are usually deep red in colour when alive, whereas the stipules of all varieties of $D$. spatulata are papery white or translucent in living plants. Unfortunately, stipules of both species turn brownish when dried, so this character is not applicable to herbarium specimens.

Drosera spatulata can be found growing in a wide range of nutrient-poor soils in Malesia, ranging from clay-based, mafic laterites, organic soils and peat to pure wet silica sand (Van Steenis 1953, Fleischmann \& Lee 2009), but it is apparently always absent in suitable habitats on ultramafic soils. Drosera spatulata is a lowland to submontane species occurring from 10-1400 m altitude (Van Steenis 1953, Conn 1980), but reaching up to $2400 \mathrm{~m}$ on Mt Halcon, Mindoro, Philippines (Merrill 1907, pers. obs.). In Sarawak, Borneo, in New Guinea and in eastern Australia, $D$. spatulata is a species of low altitude savannah and open, usually swampy, heath vegetation (Van Steenis 1947, 1972, Conn 1980, Lowrie 1998, Fleischmann \& Lee 2009). Drosera ultramafica is restricted to montane habitats (1500-3000 m). Due to their different ecological preferences, the species have not been reported as growing sympatrically, and they are unlikely to co-occur naturally. For the same reason, no natural hybrids involving $D$. ultramafica as a parent are known.

Two species of Drosera from Indochina and New Caledonia respectively are superficially reminiscent of $D$. ultramafica, but are not recorded from the Malesian area; these can be distinguished from the latter as follows: $D$. ultramafica differs from the Chinese $D$. oblanceolata Y.Z.Ruan, which has similar leaves and stipules, in having a glandular-hairy scape, sepals only occasionally reflexed in fruit (usually all five sepals of the calyx with reflexed tips in fruit, as in $D$. spatulata) and flowers with style arms widened to the tip and a stigmatic tip that is lanceolate to spathulate or bifid (filiform style arms, stigmatic tip bifid or ramifid). In addition, $D$. oblanceolata is endemic to Hong-Kong (Ruan 1981) and not expected to occur in the Malesian floristic area.

Drosera neocaledonica Raym.-Hamet, an endemic of New Caledonia, shares a similar stem-forming habit and narrowly oblan- ceolate leaves, but differs from $D$. ultramafica in having bristly white hairs on its petioles, in having a scape and sepals that are covered densely with short-stalked red glandular trichomes, and in the larger flowers (up to $2 \mathrm{~cm}$ diam) and styles with stigmatic tips that are branched multiple times.

Drosera neocaledonica is the only other species in the genus other than $D$. ultramafica that is not only tolerant of ultramafic substrates, but seemingly ecologically restricted to them (Gibson 2001). However, both taxa can be artificially cultivated in peat-based substrates devoid of high concentrations of heavy minerals (Gibson 2001, A. Fleischmann pers. obs.), suggesting that they are not edaphically confined to the soil chemistries of ultramafic regions. Most plant taxa endemic to ultramafites will grow well artificially on non-ultramafic soils in the absence of competition by vigorous plants or phytopathogenic fungi, thus ultramafic soils effectively provide a refuge from biotic factors present in non-ultramafic substrates (Brooks 1987). One other species of Drosera is known to at least tolerate ultramafic substrates: $D$. arcturi Hook. can occasionally be found growing in wet soil overlying ultramafic rocks in Tasmania (Gibson et al. 1992), but is not generally restricted to such sites, growing well in various types of non-ultramafic peaty soil (Lowrie 1998).

Acknowledgements We thank the Palawan Council for Sustainable Development (PCSD) and Department of Environment and Natural Resources (DENR) for authorising expeditions in Palawan and for permission to collect herbarium samples, Palawan State University staff for considerable administrative work, Captains Romeo B. Basas of Barangay Poblacion and Joelo R. Rotil Sr. of Barangay Princess Urduja in Narra for their permission to climb Mt Victoria and subsequent assistance with guides, Captain Ong of Barangay Ransang for allowing the Mt Mantalingahan climb, Yvette Harvey at Kew Herbarium, and Harvey John D. Garcia of Conservation International, Philippines. Urs Zimmermann is thanked for providing information and photos from Central Sulawesi. The first author thanks the curators of $L$ for loaning specimens of Malesian Drosera, and the curators of $\mathrm{M}$ for providing study access to their collection.

\section{REFERENCES}

Anfraix R. 2005. Discovery of Nepenthes edwardsiana at Marai Parai. Acta Botanica Gallica 152: 205-213.

Beaman JH, Anderson C, Beaman RS. 2001. The plants of Mount Kinabalu, 4. Dicotyledon families Acanthaceae to Lythraceae: 517, pl. 19. Natural History Publications, Kota Kinabalu, Borneo.

Brooks RR. 1987. Serpentine and its vegetation. A multidisciplinary approach. Ecology, phytogeography and physiology series 1, Dioscorides Press, Portland. 
Conn BJ. 1980. A review of Drosera in Papuasia. Brunonia 3: 209-216.

Conran JG, Jaudzems G, Hallam ND. 1997. Droseraceae germination patterns and their taxonomic significance. Botanical Journal of the Linnean Society 123: 211-223.

De Wilde WJJO, Duyfjes BEE. 2001. On the special botanical character of the Leuser Park and vicinity, with emphasis on the high mountain blang vegetation of Northern Sumatra. Flora Malesiana Bulletin 12: 377-391.

Diels L. 1906. Droseraceae. In: Engler HGA, Das Pflanzenreich 26, 4: 1136.

Fleischmann A, Lee CC. 2009. A new variety of Drosera spatulata (Droseraceae) from Sarawak, Borneo. Carnivorous Plant Newsletter 38: 4-9.

Gibson N, Brown MJ, Williams K, Brown AV. 1992. Flora and vegetation of ultramafic areas in Tasmania. Australian Journal of Ecology 17: 297-303.

Gibson R. 2001. Drosera neocaledonica: its origins, habitat, and cultivation. Carnivorous Plant Newsletter 30: 37-42.

Hutchison CS. 1975. Ophiolite in Southeast Asia. Geological Society of America Bulletin 86: 797-806.

Lowrie A. 1998. Carnivorous plants of Australia 3. University of Western Australia Press, Nedlands.

McPherson S. 2009. Pitcher plants of the Old World 1 \& 2. Redfern Natural History Publications Ltd, Dorset.

Merrill ED. 1907. The flora of Mount Halcon, Mindoro. Philippine Journal of Science. Section C, Botany 2: 251-309.
Nagy L, Proctor J. 1997. Plant growth and reproduction on a toxic alpine ultramafic soil: adaptation to nutrient limitation. New Phytologist 137 267-274.

Proctor J. 2003. Vegetation and soil and plant chemistry on ultramafic rocks in the tropical Far East. Perspectives in Plant Ecology, Evolution and Systematics 6: 105-124.

Proctor J, Woodell RJ. 1975. The ecology of ultramafic soils. Advances in Ecological Research 9: 255-366.

Robinson AS, Fleischmann A, McPherson S, Heinrich VB, Gironella EP, Peña CQ. 2009. A spectacular new species of Nepenthes L. (Nepenthaceae) pitcher plant from central Palawan, Philippines. Botanical Journal of the Linnean Society 159: 195-202.

Ruan YZ. 1981. On the Chinese species of Drosera L. Acta Phytotaxonomica Sinica 19: 339-344.

Van Beek CGG. 1982. Een geomorfologische bodemkundige studie van het Gunung Leuser Nationale Park, Noord Sumatra, Indonesië. PhD thesis University of Utrecht.

Van Steenis CGGJ. 1947. Notes on a number of New Guinea species. Journal of the Arnold Arboretum 28: 419-423.

Van Steenis CGGJ. 1953. Droseraceae. Flora Malesiana, Ser. I, 4: $377-$ 381.

Van Steenis CGGJ. 1972. Addenda, corrigenda et emendanda. Flora Malesiana, Ser. I, 6: 943. 